\title{
ANALISIS PUTUSAN HAKIM TERHADAP AHLI WARIS YANG BERBEDA AGAMA DALAM PERSPEKTIF SYARA': STUDI KASUS NO.1803/PDT.G/2011/PA. SBY.
}

\author{
Zakiul Fuady Muhammad Daud \\ IAIN Takengon, Aceh, Indonesia \\ Email: zakiul_fuady@yahoo.com
}

\begin{abstract}
Religious differences in a family in Indonesian society cannot be avoided because Indonesia is pluralist. However, in the view of Islam, this will have an impact on inheritance issues where religious differences are one of the barriers in obtaining inheritance. To overcome this, most judges give inheritance to heirs with different religions through wajibah wills. However, in this case, the judge did not give wajibah wills to heirs with different religions. The aim of this study is to find out the reason for the judge in deciding the case and to analyze the decision taken from a sharia perspective. This research is a combined study between normative juridical and empirical juridical studies where the researcher tries to analyze the judge's decision which is empirically juridical based on the sharia perspective. The results showed that the judge decided not to give wajibah wills to heirs with different religions based on article e of the Islamic law compilation regarding the qualifications of heirs. This decision is in accordance with sharia because it does not contradict the hadith and the principles in Islamic inheritance law are force (ijbari) which cannot be compromised except with other arguments.
\end{abstract}

Keywords: Heirs with Different Religions, Wajibah Will, Islamic Inharitance

\begin{abstract}
Abstrak: Perbedaan agama dalam sebuah keluarga pada masyarakat Indonesia tidak bisa dielakkan karena Indonesia bersifat pluralis. Namun demikian, dalam pandangan Islam, hal ini akan berdampak kepada masalah kewarisan dimana perbedaan agama merupakan salah satu penghalang untuk mendapatkan warisan. Untuk mengatasi hal ini kebanyakan hakim memberikan harta warisan kepada ahli waris yang berbeda agama melalui wasiat wajibah. Namun, dalam kasus ini, hakim tidak memberikan wasiat wajibah kepada ahli waris yang berbeda agama. Tujuan dari penelitian ini adalah untuk mengetahui alasan hakim dalam memutuskan perkara tersebut dan menganalisis putusan yang diambil dalam perspektif syara'. Penelitian ini merupakan penelitian gabungan antara kajian yuridis normatif dan yuridis empiris dimana peneliti mencoba menganalisis putusan hakim yang bersifat yuridis empiris berdasarkan kepada perspektif syara'. Hasil penelitian menunjukkan bahwa hakim memutuskan tidak memberikan wasiat wajibah kepada ahli waris yang berbeda agama berlandaskan kepada KHI pasal e tentang kualifikasi ahli waris. Putusan ini sudah sesuai dengan syara' karena tidak bertentangan dengan hadits dan asas dalam hukum kewarisan Islam bersifat ijbari yang tidak bisa dikompromikan kecuali dengan dalil lain.
\end{abstract}

Kata Kunci: Ahli Waris Yang Berbeda Agama, Wasiat Wajibah, Kewarisan Islam

\section{PENDAHULUAN}

Masyarakat Indonesia terkenal mayoritas beragama Islam, tetapi masyarakat Indonesia juga bersifat pluralis yang tidak hanya terdiri dari beragam suku maupun etnik, tetapi juga beragam dalam beragama (Daud \& Azahari, 2019a; Sukarna \& Hambali, 2017). Perbedaan agama ini menjadi fenomena yang biasa terjadi di Indonesia, termasuk dalam kehidupan keluarga. Terkadang dalam satu keluarga kedua orang tua beragama Islam, akan tetapi ada salah satu anaknya yang beragama selain Islam. Dalam pandangan Islam, perbedaan keyakinan ini memberikan dampak yang signifikan bagi keluarga tersebut terutama pada aspek akibat hukum yang akan diterima oleh anggota keluarga tersebut. 
Akibat hukum yang mencolok dari adanya perbedaan agama adalah berkaitan dengan masalah warisan. Pada dasarnya dalam hukum Islam, antara orang tua dan anak saling mewarisi apabila salah satunya meninggal selama mempunyai keyakinan yang sama. Akan tetapi jika keyakinan yang dimiliki anggota keluarga berbeda, maka mereka tidak dapat saling mewarisi karena beda agama merupakan salah satu hal yang menghalangi seseorang untuk mendapatkan harta warisan (Arif, 2017; Cahyono, Kusuma, \& Telussa, 2019; Daud, 2018; Daud \& Azahari, 2018; Hanum \& Syahr, 2016; Istiqamah, 2017; Raharjo \& Dwi Putri, 2019; Setiawan, 2017; Yudistiawan, 2018). Hal ini sebagaimana hadits Rasulullah SAW yang diriwayatkan oleh Bukhari dan Muslim yang artinya:

"Abu Ashim telah menceritakan dari Ibn Juraij dari Ibn Syihab dari Ali Ibn Husain dari Amr Ibn Utsman dari Usamah Ibn Zaid RA: Sesungguhnya Rasulullah bersabda: 'Orang muslim tidak boleh mendapatkan harta waris dari orang kafir, dan orang kafir tidak boleh mendapatkan warisan dari orang muslim."'(Bukhari, 1984; Muslim, 1988). Hadits ini mengisyaratkan bahwa status agama individu sebagai pewaris sangat penting ketika proses pembagian harta waris apakah ahli waris berhak mendapatkan harta warisannya atau tidak (Daud, 2018; Herenawati, Sujana, \& Kusuma, 2020), begitu juga sebaliknya.

Dalam menanggapi hal ini, sebagian pakar yang menganggap bahwa perbedaan agama menjadi penghalang mendapatkan harta warisan merupakan sebuah bentuk diskriminasi (Apriyudi, 2018). Bagi kaum minoritas dan hal ini menunjukkan bahwa aplikasi hukum Islam tidak sesuai dengan karakter Islam itu sendiri sebagai rahmatan lil alamin (Arif, 2017). Namun demikian, dalam realitanya kebanyakan putusan MA memberikan harta waris kepada ahli waris yang beragama selain Islam melalui wasiat wajibah (Daud, 2018; Daud \& Azahari, 2018) dan ini dianggap sebagai terobosan yang dapat mendongkrak eklusivisme Islam dan menangkal konsep diskriminasi dalam Islam diantaranya kasus No.0140/Pdt.P/2012/PA.SBY, No.18/Pdt.G/2007/PTA.SBY. dan 331/K/Ag/2018. Bahkan putusan Mahkamah Agung pada kasus terakhir dijadikan sebagai lendmark decision bagi para hakim rendah maupun tinggi untuk dijadikan rujukan bagi kasus-kasus pembagian ahli waris non muslim (Raharjo \& Dwi Putri, 2019).

Namun demikian, pada putusan tertentu seperti kasus No.1803/Pdt.G/2011/PA. SBY. Hakim tidak memberikan wasiat wajibah kepada ahli waris yang berbeda agama. Hal ini membuat penulis tertarik untuk mengkaji lebih mendalam bagaimana putusan yang diberikan oleh hakim pada kasus tersebut, apa alasan hakim tidak memberikan wasiat wajibah kepada mereka, dan bagaimana putusan hakim tersebut dalam perspektif syara'. Diharapkan dengan mengangkat kasus ini memberikan pertimbangan untuk menerapkan hukum waris sesuai dengan pembuat syariat.

\section{LANDASAN TEORI}

\section{Konsep Kewarisan dalam Islam}

Kata mawaris merupakan bentuk jama' dari kata mitrats (irts, wirts, turats) yang artinya harta tinggalan orang yang sudah meninggal yang akan diwarisi oleh ahli warisnya (Ash-Shiddieqy, 1987; Daud, 2018). Oleh karena itu, ilmu yang mempelajari tentang harta waris disebut sebagai ilmu waris. Muhibbin \& Wahid (2009) mengatakan 
bahwa ilmu waris adalah ilmu yang mempelajari tentang cara perpindahan harta peninggalan pewaris (mayit) kepada ahli waris serta bagian masing-masing.

Berdasarkan definisi di atas, maka obyek kewarisan adalah harta peninggalan. Oleh karena itu, harta peninggalan yang ditinggal si mayit disebut sebagai tarikah (AshShiddieqy, 1987; Daud, 2018). Berkenaan dengan tarikah ini terdapat pandangan yang berbeda diantara ulama tentang definisi tarikah. Jumhur ulama bersepakat tarikah adalah segala bentuk peninggalan mayit baik berupa harta maupun hak yang bersifat harta. Dengan demikian, tarikah dalam pandangan ini mencakup seluruh harta termasuk di dalamnya hutang, menggadaikan barang, maupun hutang yang bersifat pribadi seperti hutang mahar (Ash-Shiddieqy, 1987; Daud, 2018).

Ajaran Islam melalui al-Qur'an dan al-Hadis mengarahkan umatnya untuk membagikan harta warisan sebagaimana ketentuan yang sudah ditetapkan Allah. Siapa yang mengikuti pembagian waris sesuai ketentuan Allah, maka Allah akan berikan pahala, begitu sebaliknya siapa yang memberikan bagian harta waris tidak berdasarkan ketentuan Allah, maka ia akan mendapatkan hukuman seperti dalam surat an-Nisa' ayat 13-14 yang artinya:

"Semua hukum yang tersebut adalah batas-batas (Syariat) Allah. Dan siapa yang taat kepada Allah dan Rasulnya, akan dimasukkan oleh Allah ke dalam Syurga yang mengalir dari bawahnya beberapa sungai, mereka kekal di dalamnya; dan itulah keberuntungan yang amat besar. Dan siapa yang durhaka kepada Allah dan Rasulnya, dan melampaui batas-batas Syariatnya, akan dimasukkan oleh Allah ke dalam api neraka, kekallah dia di dalamnya, dan baginya azab yang amat menghinakan." (QS. An-Nisa': 13-14).

Hukum kewarisan Islam adalah aturan-aturan Allah yang sudah ditentukan cara penyelesaiannya. Aturan-aturan yang Allah berikan untuk manusia bertujuan sebagai rahmat bagi umat manusia atau memberikan kemaslahatan umat agar menghindarkannya dari kemudharatan (Daud, 2018; Djakfar \& Yahya, 1995). Selain itu, pada hakikatnya, hukum syara' merupakan aturan yang mudah dan sesuai dengan fitrah manusia sehingga tidak akan ada hukum syara' yang berlawanan dengan nurani setiap individu muslim. Oleh karena itu, umat harus dapat mengamalkan segala sesuatu yang diperintahkan oleh Allah sesuai kadar kemampuannya.

Praktek dalam masyarakat, sebagian muslim dapat menerima hukum kewarisan ini sehingga dalam pembagian warisan mengikuti aturan yang sudah ditentukan Allah. Namun demikian, terkadang ada sebagian orang muslim yang merasa berat hati untuk mengamalkan pembagian harta waris seperti yang diajarkan dalam Islam, sehingga mereka masih menganut kepada kebiasaan budaya setempat yang mungkin berbeda dengan aturan Islam.

Jika dilihat dari ayat-ayat mawaris, ayat-ayat tersebut bersifat qath' $i$ yang menunjukkan bagian yang sudah ditetapkan (furudh al muqaddarah), sehingga tidak ada peluang bagi akal untuk melakukan interpretasi lebih lanjut (Daud, 2018; Daud \& Azahari, 2018, 2019a, 2020, 2019b; Djakfar \& Yahya, 1995). Dengan demikian, konsep kewarisan dalam Islam bersifat ta'abbudi bukan ta'aqquli, dimana semua aturan sudah ditentukan oleh pembuat syariat, umat Islam tinggal melaksanakan aturan tersebut. Siapa 
yang menjalankannya maka dinilai sebagai ibadah, sebaliknya siapa yang melanggarnya, maka dia mendapatkan dosa. Dan konsep kewarisan dalam Islam bukan bersifat ta'aqquli bermakna bahwa pembagian harta waris yang ada dalam Islam, bukan ditetapkan berdasarkan atas pertimbangan akal manusia melainkan sudah ditetapkan oleh Allah.

\section{Asas Kewarisan dalam Islam}

Berkaitan dengan proses pemindahan tarikah kepada ahli waris, terdapat beberapa asas yang harus dipegang, yaitu asas ijbari, asas bilateral, asas individual dan asas keadilan berimbang (Daud, 2018; Muhibbin \& Wahid, 2009; Syarifuddin, 2004). Yang dimaksud dengan asas ijbari adalah dengan meninggalnya individu, maka harta yang dimiliki oleh si mayit, secara otomatis berpindah ke ahli warisnya. Di sini, berlakunya perpindahan harta disebabkan dikehendaki oleh Allah dan tidak tergantung kepada kehendak waris maupun keinginan dari ahli waris. Dan asas ijbari ini berlaku untuk semua aspek, seperti siapa yang seharusnya menjadi ahli waris, dan jumlah bagiannya itu sudah ditentukan oleh Allah. Dengan demikian, tidak ada otoritas manusia untuk memasukkan ahli waris lain dan mengeluarkan ahli waris yang semestinya mendapatkannya (Daud \& Azahari, 2019a, 2019b; Syarifuddin, 2004).

Sedangkan asas bilateral bermakna bahwa konsep peralihan harta waris dalam Islam melibatkan dua arah garis keturunan yaitu mengikuti garis keturunan perempuan dan garis keturunan laki-laki (Daud, 2018; Syarifuddin, 2004). Asas bilateral menjelaskan bahwa gender bukan menjadi halangan untuk mendapatkan harta waris ataupun mewarisi (Daud, 2018; Muhibbin \& Wahid, 2009). Sebagai contoh ayat 7 surat an-Nisa' menjelaskan bahwa anak laki-laki mempunyai hak untuk mendapatkan harta waris dari ayah dan ibunya, begitu juga anak perempuan juga mendapatkan bagian harta waris dari kedua orangtuanya apabila meninggal dunia (Daud, 2018; Syarifuddin, 2004). Dengan demikian, asas bilateral ini memberikan kesempatan yang sama antara kaum lelaki dan perempuan, baik dari garis keturunan ayah maupun ibu sehingga keadilan dapat dicapai.

Sementara itu, asas individual memberikan makna bahwa tiap-tiap ahli waris yang ditetapkan mendapatkan bagian, menerima jatahnya secara individual yang tidak tersangkut dengan bagian ahli waris yang lain (Syarifuddin, 2004). Ini disebabkan masing-masing ahli waris sudah mendapatkan bagian sesuai kadar yang ditentukan oleh Allah. Asas ini dapat dilihat dari ayat-ayat mawaris yang masing-masing ahli waris mempunyai bagian tertentu walaupun terkadang dalam prakteknya terdapat ahli waris yang mendapatkan bagian secara bersama-sama. Misalnya jika si mayit meninggalkan istri, seorang anak laki-laki dan seorang anak perempuan, maka bagian anak perempuan awalnya bergabung dengan anak laki-laki. Namun demikian pada pembagian selanjutnya akan dibagikan secara individual dimana anak lelaki mendapatkan dua bagian anak perempuan.

Sedangkan asas keadilan berimbang bermakna adanya keserasian antara jumlah harta waris yang diperoleh dengan kewajiban yang dipikulnya. Dalam hukum kewarisan Islam, baik laki-laki maupun perempuan keduanya berhak memperoleh harta waris. Dengan perkataan lain, jika anak laki-laki mendapatkan harta waris, maka anak perempuan juga mendapatkan bagian. Di sini terkadang perempuan mendapatkan bagian yang sama besarnya dengan bagian laki-laki, seperti kasus meninggalnya anak yang meninggalkan ahli waris bapak dan ibunya serta anak lelaki. Maka bagian bapak sama 
dengan bagian ibu yaitu 1/6. Namun terkadang laki-laki mendapatkan bagian yang lebih banyak dibandingkan dengan bagian perempuan, seperti anak laki-laki mendapatkan dua bagian anak perempuan, saudara laki-laki mendapatkan bagian dua saudara perempuan.

Jika dilihat dari jumlah yang diperoleh, nampak terdapat ketidakadilan. Namun demikian, kondisi ini bukan menunjukkan ketidakadilan karena keadilan menurut Islam tidak hanya dilihat dari besaran yang sama melainkan berkait erat dengan manfaat dan kebutuhan. Seorang lelaki mempunyai kebutuhan yang lebih banyak dibandingkan seorang perempuan karena dia mempunyai tanggungjawab yang dobel, yaitu tanggungjawab terhadap dirinya dan keluarganya termasuk terhadap istrinya (Syarifuddin, 2004) bahkan terhadap ibunya jika ibunya masih hidup sebagaimana dalam surat an-Nisa' ayat 34 yang artinya:

"Kaum laki-laki itu adalah pemimpin bagi kaum wanita, karena Allah telah melebihkan sebagian mereka (laki-laki) atas sebagian yang lain (wanita), dan karena mereka (laki-laki) telah menafkahkan sebagian dari harta mereka" (QS. 4: 34).

Asas kewarisan dalam Islam yang terakhir adalah asas semata-mata akibat kematian yaitu terjadinya perpindahan harta warisan dari individu kepada individu lain setelah yang mempunyai harta meninggal dunia. Ini bermakna bahwa apabila individu muslim memberikan hartanya kepada yang lain ketika masih hidup, maka harta tersebut bukan dinamakan sebagai harta waris, walaupun pelaksanaannya dilakukan setelah dia meninggal dunia. Asas ini diambil dari banyaknya penggunaan kata "waratsa" dalam alQur'an yang mengandung makna berpindahnya sesuatu dari yang mewariskan kepada ahli waris setelah yang mewariskan itu meninggal dunia (Syarifuddin, 2004).

Selain dari lima asas di atas, Djakfar dan Yahya (1995) mengimbuhkan asas personalitas ke dalam asas kewarisan Islam dimana asas ini menghendaki peralihan harta dalam kewarisan hanya terjadi apabila antara yang mewarisi dan yang menerima warisan sama-sama beragama Islam. Asas ini menunjukkan bahwa tidak diperbolehkan seorang muslim mewarisi ahli warisnya yang berbeda agama dengannya sehingga secara mutlak dia tidak berhak menerima harta warisan.

\section{Penghalang untuk Mendapatkan Harta Waris}

Jumhur ulama bersepakat bahwa penyebab seseorang tidak mendapatkan harta waris (al-hijab bil wasfi) ada tiga; yaitu pembunuhan, budak, dan beda agama (Abd. Hamid, 2009; Ash-Shabuni, 1995). Walau bagaimanapun, terdapat juga penghalang mendapatkan harta waris yang masih diperdebatkan oleh ulama, seperti murtad, berlainan negara, dan intervensi pemerintah melalui keputusan hakim (ad-daur al-hukmi) (Abd. Hamid, 2009; Ash-Shiddieqy, 1987; Muhibbin \& Wahid, 2009).

Berkaitan dengan pembunuhan, Rasulullah menegaskan bahwa pembunuh yang membunuh salah seorang anggota keluarganya, maka si pembunuh sama sekali tidak boleh menerima pusaka (Abd. Hamid, 2009; Daud, 2018). Ini berdasarkan kepada hadis Rasulullah SAW yang artinya: "Tak ada pusaka bagi si pembunuh". (HR. Malik dan Ahmad dari Umar). Berdasarkan hadis ini, para ushuliyyin membuat sebuah kaedah "Orang yang mendahului sebelum waktunya, maka akan dihukum dengan tidak diberikan bagian yang seharusnya ia dapatkan" (Abd. Hamid, 2009). Maka, pembunuhan merupakan sebuah dosa besar dan dianggap sebagai suatu jarimah yang akan dibalas oleh 
Allah dengan azab yang paling berat karena menjadikan maksiat sebagai jalan untuk mendapatkan kenikmatan dan keuntungan (Abd. Hamid, 2009).

Sedangkan penghalang kedua adalah budak. Pada masa dulu, budak ada dimanamana, sehingga sangat sulit untuk diatasi. Islam sangat menghargai manusia dan ingin menghilangkan adanya perbudakan. Oleh karena itu, perbudakan juga menjadi tumpuan utama dalam hukum Islam seperti kafarat melakukan dhihar adalah dengan membebaskan budak. Dalam hal ini, seseorang yang menjadi budak selamanya terputus hubungan kekeluargaan dengan kerabatnya sehingga apabila ia meninggal, tidak dapat mewariskan hartanya kepada anaknya sekalipun (Abd. Hamid, 2009).

Yang terakhir golongan yang tidak berhak mendapatkan waris adalah berbeda agama. Yang dimaksud di sini adalah agama si mayit berbeda dengan agama ahli waris yang akan mendapatkan harta waris. Para ulama bersepakat bahwa agama yang berbeda antara pewaris dan ahli waris menghalangi ahli waris untuk mendapatkan harta waris. Dengan kata lain, seorang kafir tidak akan mendapatkan harta waris dari keluarganya yang muslim baik melalui hubungan kekerabatan maupun hubungan kekeluargaan, begitu juga sebaliknya. Hal ini berdasarkan kepada keumuman hadis dari Usamah bin Zaid yang diriwayatkan oleh Bukhari dan Muslim yang artinya:

"Seorang muslim tidak boleh mendapatkan warisan dari seorang kafir. Dan seorang kafir tidak boleh mendapatkan warisan dari seorang muslim". (HR. Bukhari dan Muslim).

Berkaitan dengan hal ini, para ulama berbeda pendapat terhadap apakah seorang kafir dapat menerima harta waris jika ia masuk Islam setelah si mayit meninggal dan sebelum harta waris dibagikan? (Abd. Hamid, 2009). Menurut Imam Malik, Imam Abu Hanifah, dan Imam Syafi'i menyatakan bahwa orang kafir tidak mempunyai hak mendapatkan harta waris dari seorang muslim dengan sebab pewarisan apapun, baik melalui wala', pernikahan maupun kekerabatan. Sedangkan menurut Imam Ahmad bin Hambal menyatakan bahwa orang kafir boleh mendapatkan harta waris dari orang muslim apabila ia masuk Islam sebelum harta waris dibagikan (Abd. Hamid, 2009).

\section{Wasiat Wajibah}

Pembahasan tentang wasiat wajibah tidak terlepas dari wasiat itu sendiri. Namun jika istilah wasiat digabungkan dengan wajibah, maka mempunyai arti yang agak berbeda dengan makna wasiat itu sendiri. Pada dasarnya, wasiat dilakukan dengan kerelaan (ikhtiyarah) dan keinginan sendiri sehingga individu bebas untuk berwasiat atau tidak (Muhibbin \& Wahid, 2009). Namun jika wasiat digabungkan dengan wajibah, maka maknanya menjadi wasiat yang diwajibkan (Ash-Shiddieqy, 1987; Daud, 2018). Secara istilah, berdasarkan pandangan imam fiqh dan sebagian fuqaha' tabi'in, wasiat wajibah adalah wasiat yang harus dibagikan kepada anggota keluarga yang tidak mendapatkan jatah harta pusaka, seperti firman Allah dalam surat al-Baqarah ayat 180 yang artinya: "Diwajibkan atas kamu, apabila seorang di antara kamu kedatangan (tanda-tanda) maut, jika ia meninggalkan harta yang banyak, berwasiat untuk ibu bapa dan karib kerabatnya secara ma'ruf, (Ini adalah) kewajipan atas orang-orang yang bertaqwa..." (QS. al-Baqarah, 2: 180). 
Menurut Usman \& Somawinata (1997), wasiat wajibah adalah wasiat yang eksekusinya tidak tergantung kepada keinginan orang yang meninggal, tetapi harus dieksekusi baik itu diucapkan ataupun tidak. Pembagian melalui wasiat wajibah ini bukan karena adanya bukti wasiat dari yang berwasiat melainkan dikarenakan alasan-alasan hukum tertentu. Lebih dari itu, Ibn Hazm yang berpandangan bahwa apabila tidak diadakan wasiat untuk kerabat yang tidak mendapatkan harta waris, maka hakim harus mengambil sikap memberikan sebagian harta waris kepada mereka sebagai wasiat yang wajib diberikan untuk mereka (Ash-Shiddieqy, 1987). Seperti cucu yang tidak mendapatkan harta warisan dari kakeknya karena terhalang oleh paman mereka. Abdul Manan (1998) juga mendukung pandangan Ibn Hazm dimana wasiat wajibah merupakan keputusan yang ditentukan dan dilaksanakan oleh hakim sebagai pemerintah negara untuk memberikan wajib wasiat bagi orang yang meninggal dunia kepada individu tertentu dalam keadaan tertentu. Dari definisi yang diberikan oleh para ahli, maka dapat disimpulkan bahwa wasiat wajibah terdiri dua unsur (Daud \& Azahari, 2018), yaitu:

a. Tidak membutuhkan kerelaan orang yang berwasiat untuk memberikan wasiat. Hal ini mengisyaratkan bahwa biarpun yang meninggal tidak menyatakan wasiat, tetapi tetap dianggap berwasiat.

b. Hakim yang berperan sebagai pewasiat untuk membagikan harta paling banyak sepertiga harta orang yang meninggal tersebut untuk dibagikan kerabat yang terhalangi untuk menerima warisan.

Pada hakikatnya istilah wasiat wajibah adalah sesuatu yang baru popular pada abad ke-20 dan istilah ini tidak ditemukan dalam manuskrip-manuskrip fiqh klasik (Khairani, 2012). Maka dari itu, bagaimana hukum wasiat wajibah itu dalam perspektif Islam merupakan sesuatu kontroversial dan membutuhkan ijtihad serta istinbat hukum oleh ulama. Dalam hal ini terdapat perbedaan pendapat di antara para ulama dimana ada yang membolehkan memberikan wasiat wajibah dan sebagian ulama lainnya tidak membolehkan memberikan wasiat wajibah.

Kelompok yang membolehkan wasiat wajibah adalah Abī Abī 'Abd Allāh'Abd Allāh Muḥammad bin 'Umar al-Razi, Sayyid Quthb, Muḥammad Abduh, Said bin Jabir, Rabi' bin Anas, Qatadah, Muqatil bin Hayyan, Ibn 'Abbās, dan al-Hasan (Usman \& Somawinata, 1997). Dan pandangan ini merupakan pegangan Ibn Hazm. Alasan yang mereka gunakan: pertama, adanya kewajiban pada surah al-Baqarah ayat 180 hanya dilakukan kepada walidain (orangtua) dan aqrabin (sanak kerabat) yang terhalang atau yang tidak menjadi ahli waris (Al-Jashash, n.d.; Al-Qurtubī, 1999; Ridha, n.d.). Hal ini dijelaskan oleh Ibn Hazm yang mengatakan bahwa perintah memberikan wasiat dalam ayat wasiat masih tetap ada dan berhukum wajib. Perintah yang ditiadakan ditujukan hanya kepada anggota keluarga yang telah menjadi ahli waris. Sehingga apabila seorang Muslim wafat dan tidak meninggalkan wasiat apapun sebelumnya, maka ahli waris wajib memberikan sebagian harta warisannya (Hazm, 1983). ${ }^{\text {i }}$ Lebih dari itu, jika kewajiban ini tidak dilaksanakan, maka pengadilan yang berperan sebagai penguasa (ulul amri) berkewajiban memberikan wasiat untuk memenuhi kewajiban wasiat ini (Al-'Ainani, 1982). 
Sedangkan kelompok yang tidak membolehkan adanya wasiat wajibah adalah mayoritas ulama yang menyepakati bahwa hukum memberikan wasiat kepada sanak saudara yang tidak berhak memperoleh harta warisan adalah sunnah. Dalam hal ini, hujjah yang digunakan oleh mayoritas ulama adalah pertama, lafaz kutiba dalam surah alBaqarah ayat 180 sudah dinasakh oleh ayat-ayat mawārits yang sudah menjelaskan bagian masing-masing ahli waris seperti orangtua, dan sanak kerabat dengan ketentuan yang sudah pasti (Khairani, 2012). Kedua, kewajiban dalam ayat wasiat ini juga sudah dinasakh oleh hadis Rasulullah SAW yang artinya:

"dari Abü Umamah RA berkata: saya mendengar Rasulullah SAW bersabda dalam salah satu khutbah beliau pada tahun haji wada' bahwa Allah telah memberikan hak kepada siapa yang berhak. Oleh karena itu, tidak ada hak untuk mendapatkan wasiat bagi para ahli waris..."(Al-Tirmidhi, 1977; Ibnu Mājah, 1999) (Khairani, 2012).

Ketiga, secara historis, Rasulullah SAW dan rata-rata sahabat tidak mempraktikkan memberikan wasiat kepada sanak famili (Abu Bakar, 1989). Keempat, mayoritas ulama mengkaitkan antara kata kutiba dengan khairan. Oleh karena itu, mereka lebih condong mengemukakan bahwa kewajiban memberikan wasiat hanya untuk orang-orang kaya atau yang mencapai batas harta (Al-Maraghi, 1974; Ridha, n.d.). Dengan demikian, mayoritas ulama tidak lagi memberikan makna kata kutiba dengan diwajibkan, bahkan apabila ada seorang Muslim yang menyatakan wasiat untuk ahli waris, maka hukumnya tidak sah atau batal (Khairani, 2012).

\section{METODE PENELITIAN}

Penelitian ini menggunakan pendekatan gabungan antara kajian yuridis normatif atau normatif legal research (law in book) dan kajian yuridis empiris (law in action) terhadap regulasi wasiat wajibah yang tertuang pada Kompilasi Hukum Islam (KHI) dan prakteknya melalui putusan-putusan hakim oleh Mahkamah Agung dan Pengadilan Agama di Jawa Timur. Desain penelitian ini adalah penelitian kualitatif yang titik fokusnya kepada realitas yang telah dan sedang terjadi. Melalui desain penelitian ini, peneliti dapat memahami hukum kewarisan secara mendalam tentang realitas yang menjadi fokus penelitian (Piaw, 2006), dalam hal ini adalah ahli waris yang berbeda agama. Oleh karena itu, peneliti bertujuan untuk mengeksplorasi alasan hakim dalam perkara wasiat wajibah dengan meneliti kembali putusan-putusan hakim dengan semua peraturan-peraturan yang sudah ada dan pendekatan syara'.

\section{HASIL DAN PEMBAHASAN}

\section{Alasan Hakim Tidak Memberikan Wasiat Wajibah kepada Ahli Waris Non-Muslim pada Kasus No.1803/Pdt.G/2011/PA. SBY.}

Sebelum peneliti menguraikan alasan hakim dalam memberikan putusan pada kasus ini, peneliti akan memaparkan permasalahannya yaitu seorang laki-laki (Islam) mempunyai saudara sebanyak 4 orang (Islam) menikah dengan seorang perempuan (Islam) yang mempunyai 5 saudara (Islam). Setelah menikah, mereka tidak mempunyai anak. Sang suami menikah lagi dengan istri lain di lain daerah dan mempunyai seorang anak perempuan (Kristen). Anak perempuan ini dibesarkan oleh ayah dan istri pertama. 
Mereka juga mengangkat seorang anak lain secara adat. Di samping itu, mereka juga mengasuh adik sang istri. Kedua suami istri tersebut meninggal dan meninggalkan sejumlah harta waris. Dalam kasus ini yang menjadi pewaris adalah ayah yang beragama Islam dan meninggalkan anak yang beragama Kristen. Disebabkan perbedaan agama ini, maka hakim memutuskan sang anak terhalang dari menerima harta pusaka juga tidak menerima bagian melalui wasiat wajibah (mani'ul irtsi).

Adapun dasar hukum yang dijadikan landasan oleh hakim dalam memberikan putusan tersebut adalah sebagaimana pada pasal 171 huruf e KHI yang berbunyi:

"ahli waris adalah orang yang ketika meninggal dunia mempunyai hubungan darah atau hubungan pernikahan dengan pewaris, beragama Islam dan tidak terhalang oleh sebab hukum untuk menjadi ahli waris.” (Kompilasi Hukum Islam, 2001, p. 83).

\section{Analisis Putusan Hakim dalam Perspektif Syara'}

Berdasarkan putusan di atas, maka secara umum dalam pandangan penulis, putusan tersebut sesuai dengan syara'. Dimana hakim tidak memberikan harta pusaka kepada anak (pewaris) yang beragama Kristen karena ia tergolong kepada mani'ul irtsi. Putusan ini selaras dengan hadist dari Usamah Ibn Zaid yang diriwayatkan oleh Imam Bukhari dan imam Muslim. Selain itu, jika merujuk kepada maqāșid al-khamsah, maka perhatian terhadap hifd ad-din harus menjadi fokus utama dalam putusan apapun dan ini dilakukan oleh hakim tersebut. Di samping itu, hakim juga merujuk kepada regulasi yang terdapat dalam KHI yaitu pasal 171 huruf (e) berisi tentang kriteria yang menjadi ahli waris, di mana selain harus mempunyai hubungan darah juga harus yang beragama Islam. Dengan demikian, putusan hakim ini tidak keluar dari ketentuan yang terdapat dalam KHI (Daud \& Azahari, 2019b).

Hasil penelitian ini tidak mendukung penelitian yang dilakukan oleh Herenawati et al. (2020) dimana hakim memutuskan pemberian wasiat wajibah kepada ahli waris yang berbeda agama dengan alsaan hadits yang diriwayatkan oleh Imam Bukhari dan Imam Muslim dari Usamah Ibn Zaid dianggap sebagai perkataan Umar bin Khattab, bukan sabda nabi Muhammad SAW. Di samping itu, kafir yang dimaksud dalam hadits tersebut tidak diketahui kafir yang bagaimana, padahal nabi selalu mengkategorikan kekafiran individu. Dan dalam penelitian tersebut, hakim berpegang pada hukum yang terdapat pada KHI dimana dalam KHI tidak dijelaskan bahwa salah satu yang menghalangi seseorang mendapatkan harta warisan adalah perbedaan agama, hanya karena pembunuhan dan kejahatan yang menghalangi seseorang mendapatkan harta waris. Sebagai tambahan mereka berargumen bahwa hubungan kekerabatan lebih diutamakan daripada perbedaan agama. Artinya hubungan darah lebih kuat walaupun mereka berbeda agama misalnya hubungan anak dan ibu tidak akan terputus walaupun sudah berbeda keyakinan. Sehingga anak ataupun ahli waris harus mendapatkan harta warisan walaupun mempunyai keyakinan yang berbeda. Dan Islam tidak mengajarkan umatnya untuk membenci keluarganya apabila telah murtad dari agama Islam.

Menanggapi alasan yang diberikan pada penelitian Herenawati et al. (2020), jika berpedoman pada KHI, memang dalam KHI tidak dijelaskan secara eksplisit bahwa perbedaan agama menjadi penyebab menghalangi mendapatkan harta warisan. Akan tetapi, pada pasal 171 huruf e sudah dipaparkan bahwa yang menjadi ahli waris adalah 
individu yang mengalir darah yang sama dan beragama Islam baik antara pewaris maupun ahli waris. Pasal ini bisa dijadikan sebagai pedoman untuk tidak menjadikan anggota keluarga sebagai ahli waris jika agamanya bukan Islam. Selain itu, jika hakim ingin mencari sebuah hukum yang tidak ditemukan dalam KHI, maka seharusnya hakim kembali kepada hukum Islam yang bersumber kepada al-Qur'an dan hadits. Dimana dalam hukum kewarisan Islam, keyakinan yang berbeda merupakan salah satu menjadi penyebab seseorang terhalang mendapatkan harta warisan. Hal ini berdasarkan kepada hadits yang diriwayatkan oleh Imam Bukhari dan Imam Muslim yang terakui ketsiqahannya dan bersambung sanadnya dari Usamah Ibn Zaid kepada Rasulullah SAW. Hadits ini adalah hadits shahih dan merupakan sabda Rasulullah, bukan pernyataan Umar Bin Khattab, sehingga hadits ini bisa dijadikan sebagai hujjah. Dalam hadits ini kata-kata kafir bersifat umum, sehingga siapa saja yang telah kafir ataupun murtad dari agama Islam ketika pewaris sudah meninggal dunia, maka dia tidak berhak mendapatkan harta warisan.

Putusan yang diberikan oleh hakim dalam kajian ini juga tidak sejalan dengan kajian yang dilakukan oleh Mutmainah \& Sabir (2019) yang menyimpulkan bahwa pemberian wasiat wajibah kepada ahli waris yang berbeda agama tidak menyalahi hadits Rasulullah SAW dari Usamah bin Zaid karena anggota keluarga yang berbeda agama tidak dijadikan sebagai ahli waris, melainkan diberikan harta waris melalui wasiat wajibah. Alasan yang digunakan hakim dalam memberikan putusan tersebut adalah untuk mencapai kemaslahatan yang menjadi tujuan penetapan syariat dimana kemaslahatannya berupa keadilan sosial yang diperoleh seluruh anggota keluarga walaupun berbeda agama.

Menurut penulis, hakim sebelum memutuskan memberikan wasiat wajibah ataupun tidak, harus merujuk dan memperhatikan kepada asas kewarisan di mana salah satunya adalah asas ijbari. Asas ijbari di sini bermakna bahwa setelah pewaris meninggal, maka suka atau tidak suka, baik atau tidak baik ahli waris dengan pewaris, harta peninggalan pewaris dibagikan kepada ahli warisnya secara otomatis. Ini merupakan ketentuan Allah yang bukan didasarkan kepada perasaan atau emosi seseorang melainkan kepada maqāsșid al-sharī'ah.

Hasil penelitian ini berbeda dengan hasil penelitian yang dilakukan oleh Hanum \& Syahr (2016) yang menyimpulkan bahwa pemberian wasiat wajibah merupakan penyelesaian perkara tentang kewarisan terhadap ahli waris yang berbeda agama. Wasiat wajibah dianggap sebagai solusi yang tepat karena mencerminkan keadilan, kemanfaatan dan kepastian hukum bagi pencari keadilan. Jika dianalisis berdasarkan pendapat imam empat, keputusan pemberian wasiat wajibah bukanlah solusi yang tepat bagi ahli waris yang berbeda agama. Hal ini bisa dilihat dimana para imam empat bersepakat bahwa ahli waris yang berbeda agama tidak bisa mewarisi dengan orang muslim sekalipun melalui perbudakan dan pernikahan. Artinya walaupun antara ahli waris dan pewaris mempunyai hubungan darah akibat diikat oleh pernikahan, tetap ahli waris yang berbeda agama tidak berhak dan terhalang untuk mendapatkan harta warisan. Dalam hal ini jika merujuk kepada asas keadilan dalam hukum waris Islam, bukan keadilan merata tetapi keadilan berimbang, dimana keadilan yang diberikan sesuai tanggung jawab yang dimilikinya (Syarifuddin, 2004). Sebagai contoh, ada seorang anak yang ditinggal mati oleh ayahnya, 
maka yang berhak menjadi wali adalah saudara laki-laki bapaknya yang beragama Islam dan pamannya tersebut mempunyai tanggungjawab untuk mengasuh anak tersebut. Jika pamannya beragama Islam, maka sang paman berhak mendapatkan harta waris. Sehingga di sini terlihat paman mendapatkan hak harta waris tetapi juga mempunyai tanggung jawab untuk merawat anak tersebut. Sebaliknya, jika sang paman beragama Kristen, tentu saja sang paman tidak bisa menjadi wali sang keponakan dan dia juga tidak berhak mendapatkan harta waris. Di sini nampak bahwa keadilan yang dikehendaki dalam kewarisan Islam adalah keadilan berimbang bukan keadilan merata.

Hasil penelitian ini didukung oleh penelitian yang dilakukan oleh Hasbi (2018) yang menyatakan bahwa sebagai tindakan preventif terjadinya konflik kewarisan beda agama, maka dalam Undang-Undang perkawinan di Indonesia sudah ditetapkan bahwa perkawinan yang sah adalah perkawinan yang dilakukan oleh pasangan yang seagama. Undang-undang perkawinan ini berarti bahwa agar tidak lahir dari keturunan pasangan muslim, maka diharuskan kedua pasangan mempunyai keyakinan yang sama sehingga diharapkan akan lahir keturunan yang seagama yang berimbas kepada pemerolehan hak waris jika salah satu orang tuanya meninggal dunia. Dan Hasbi (2018) menyatakan bahwa jika pernikahan dilakukan oleh pasangan yang beda agama, maka perkawinannya dianggap tidak sah dan karena tidak sah, maka anak yang lahir dari perkawinan tersebut dianggap sebagai anak yang lahir di luar nikah sehingga hak kewarisannya hanya berhubungan dengan ibunya saja tidak dengan bapaknya. Namun demikian, dikarenakan fenomena adanya keluarga yang antara suami dan istri berbeda agama, mereka tidak bisa saling mewarisi tetapi mereka bisa mendapatkan harta dari satu sama lainnya melalui hibah, hadiah maupun wasiat dan inilah hasil Fatwa Munas VII Majelis Ulama Indonesia (MUI) Nomor 5/MUNAS-VII/MUI/9/2005 (Hasbi, 2018).

Hasil penelitian ini berbeda dengan penelitian yang dilakukan oleh Yudistiawan (2018) dimana pemberian wasiat wajibah terhadap ahli waris yang berbeda agama dianggap responsif terhadap HAM dan tidak bertentangan dengan al-Qur'an, hadis, fiqih dan KHI. Dan ijtihad yang digunakan oleh hakim dinamakan ijtihad intiqa'i dimana hakim menerapkan hukum sebagaimana yang terdapat pada hukum wasiat biasa dimana wasiat boleh diberikan kepada siapa saja tanpa memandang perbedaan keyakinan.

Menanggapi penelitian di atas, maka peneliti sepakat bahwa pemberian harta melalui wasiat boleh diberikan kepada siapapun, sekalipun kepada orang yang berbeda agama. Namun demikian, peneliti kurang sependapat jika wasiat wajibah disamakan kedudukannya dengan wasiat biasa. Hal ini disebabkan adanya perbedaan yang mendasar antara wasiat wajibah dengan wasiat biasa. Kalau wasiat biasa diberikan atas kehendak yang berwasiat tanpa ada paksaan dan wasiatnya dilakukan sebelum yang bersangkutan meninggal dunia. Artinya pemberian wasiat memang disadari dan disetujui oleh pewasiat karena itu merupakan kehendaknya sendiri. Sementara, wasiat wajibah dilakukan bukan atas dasar kehendak pewasiat karena wasiat tersebut dilakukan oleh orang lain setelah yang bersangkutan meninggal dunia, padahal belum tentu pewasiat rela untuk memberikan hartanya kepada orang ahli waris yang berbeda agama. Seandainya pewasiat memahami bahwa ahli waris yang berbeda agama tidak bisa menjadi ahli waris, tentu dia akan berwasiat jauh-jauh hari sebelum dia meninggal. Sekiranya yang meninggal tidak 
mempunyai pemahaman tersebut, maka solusi untuk masalah ini agar tidak bertentangan dengan al-Qur'an dan hadis adalah melalui hibah maupun wasiat.

Di samping itu, menurut peneliti, pemberian wasiat wajibah merupakan hal yang bersifat kontroversial, dimana terdapat perbedaan pendapat di kalangan ulama fiqh dan jumhur ulama bersepakat tidak ada wasiat wajibah dalam hukum kewarisan Islam. Pendapat jumhur yang yang dipegang oleh peneliti dengan alasan bahwa salah satu asas dalam hukum kewarisan adalah asas ijbari yang bermakna bahwa regulasi yang terdapat pada hukum kewarisan Islam itu bersifat memaksa dan sebagian besar sudah diatur oleh pembuat syariat, baik itu penerima warisan maupun jumlah bagian yang diperoleh. Oleh karena itu, menurut peneliti, hukum kewarisan dalam Islam bersifat ta'abbudi yang jika menjalankan aturan yang Allah dan RasulNya tetapkan merupakan bentuk pengamalan ibadah sebagaimana ibadah-ibadah lainnya yang jika tidak dikerjakan maka berdampak kepada perbuatan dosa. Oleh karena itu seharusnya hakim berhati-hati dalam menetapkan putusan terkait dengan hal-hal yang masih bersifat kontroversi yang secara eksplisit tidak dijelaskan dalam sumber ajaran Islam, yaitu al-Qur'an dan hadist.

\section{KESIMPULAN}

Putusan hakim terhadap kasus beda agama dimana sang ayah beragama Islam yang bertindak sebagai pewaris dan anak beragama Kristen yang merupakan ahli warisnya tidak mendapatkan harta waris dari ayahnya sekalipun melalui wasiat wajibah. Putusan ini diambil oleh hakim berlandaskan kepada pasal 171 huruf e KHI (Kompilasi Hukum Islam) yang menyatakan bahwa yang dimaksud dengan ahli waris adalah orang yang mempunyai hubungan darah atau diikat oleh ikatan pernikahan serta beragama Islam dan tidak masuk dalam kategori yang terhalang menerima harta waris.

Putusan yang diambil oleh hakim sudah sesuai dengan syara' karena berdasarkan hadist dari Usamah bin Zaid yang intinya tidak bisa saling mewarisi antara muslim dengan kafir. Di samping itu, tujuan dari adanya aturan Allah adalah untuk mencapai maqāșid al-sharī'ah dimana menjaga agama lebih didahulukan daripada aspek lainnya. Maka tidak memberikan wasiat wajibah kepada ahli waris yang berbeda agama juga merupakan bentuk keadilan berimbang. Dalam hal ini, sebagai solusi dalam kasus ahli waris yang berbeda agama adalah dengan memberikan harta kepada mereka melalui wasiat biasa, hibah maupun hadiah.

\section{DAFTAR PUSTAKA}

Abd. Hamid, M. M. (2009). Panduan Waris Empat Madzhab (W. Abdurrahim, Ed.). Jakarta: Pustaka Al-Kautsar.

Abu Bakar, A.-Y. (1989). Ahli Waris Sepertalian Darah: Kajian perbandingan terhadap penalaran Hazairin dan penalaran fikih madzhab. Disertasi. Yogyakarta: IAIN Sunan Kalijaga, Yogyakarta.

Al-'Ainani, B. A. (1982). Ahkām al-Wasāyā wa'l-Auqaf. Alexandria: Muassasa Shabāb al-Jamī'a.

Al-Jashash. (n.d.). Aḥām al-Qur'an Vol 2. Beirūt: Dār al-Kitab al-Arabi.

Al-Maraghi, A. M. (1974). Tafsir al-Maraghi, Volume IV. Qāhirah: al-Bab al-Halabi.

Al-Qurtubī, M. bin A. (1999). Al-Jam̄̄' li Ahkām Al-Qur'ān, vol. 3. Cairo: Dār al-Hadīth. 
Al-Tirmidhi, M. bin 'Īsa bin S. (1977). Bāb fĩ nafaqa al-mar'ati min baiti zaujihā. In alJamı̄’ al-Sahīh Sunan al-Tirmidhi. Cairo: Mustafa al-Bābi al-Halabī.

Apriyudi, E. (2018). Pembagian harta waris kepada anak kandung non muslim melalui wasiat wajibah. Kertha Patrika, 40(01), 45-60. https://doi.org/10.24843/kp.2018.v40.i01.p05

Arif, M. R. (2017). Pemberian wasiat wajibah terhadap ahli waris beda agama (Kajian perbandingan hukum antara Hukum Islam dan Putusan Mahkamah Agung Nomor 368.K/AG/1995). De Lega Lata: Jurnal Ilmu Hukum, 2(2), 351-372. https://doi.org/10.31219/osf.io/9f5cj

Ash-Shabuni, M. A. (1995). Pembagian Waris Menurut Islam. Jakarta: Gema Insani.

Ash-Shiddieqy, M. H. (1987). Fiqih Mawaris. Semarang: PT. Pustaka Riski Putra.

Bukhari, I. (1984). Shahih al-Bukhari. Kairo: Dar al-Hadits.

Cahyono, D. N., Kusuma, B. A., \& Telussa, J. E. I. (2019). Pembagian harta warisan orangtua yang berbeda agama dalam perspektif hukum Islam. Perspektif, 24(1), 1929.

Retrieved from http://jurnal-perspektif.org/index.php/perspektif/article/view/702

Daud, Z. F. M. (2018). Belajar Praktis Fiqih Mawaris (I. Rusuli, Ed.). Takengon: Shakura.

Daud, Z. F. M., \& Azahari, R. (2018). Amalan penghakiman dalam kes wasiat wajibah kepada waris berbeza agama: Kajian kes Terpilih. Jurnal Syariah, 26(2), 267-294. https://doi.org/10.22452/js.vol26no2.4

Daud, Z. F. M., \& Azahari, R. (2019a). The wajibah will: Alternative wealth transition for individuals who are prevented from attaining their inheritance. International Journal of Ethics and Systems, Vol. ahead-of-print No. ahead-of-print. https://doi.org/10.1108/IJOES-09-2018-0133

Daud, Z. F. M., \& Azahari, R. (2020). Analisis keputusan dan metode penghakiman terhadap pemberian wasiat wajibah kepada anak tidak sah taraf dalam kes no. 0257/PDT.G/2012/PA.JBG. Jurnal Fiqh, 17(1), 1-32. https://doi.org/10.22452/fiqh.vol17no1.1

Daud, Z. F. M., \& Azahari, R. B. (2019b). Menyoal Rekontruksi Maqashid Dalam Pembaharuan Hukum Kewarisan Islam. Jurnal Ilmiah Islam Futura, 18(1), 1-33. https://doi.org/10.22373/jiif.v18i1.2843

Djakfar, I., \& Yahya, T. (1995). Kompilasi Hukum Kewarisan Islam. Jakarta: PT. Dunia Pustaka Jaya.

Hanum, Z., \& Syahr, A. (2016). Wasiat wajibah sebagai wujud penyelesaian perkara waris beda agama dalam perkembangan sosial masyarakat. Holistik: Journal For Islamic Social Sciences, 1(2), 123-133. http://dx.doi.org/10.24235/holistik.v1i2.905

Hasbi, H. (2018). Analisis hak mewaris anak yang lahir dari perkawinan beda agama. AlIshlah: Jurnal Ilmiah Hukum, 2(1), 37-49. https://doi.org/10.33096/aijih.v21i1.15

Hazm, I. (1983). Al-Muhalla, vol. 9. Beirut: Dār al-Fikr.

Herenawati, K., Sujana, I. N., \& Kusuma, I. M. H. (2020). Kedudukan harta warisan dari pewaris non muslim dan penerapan wasiat wajibah bagi ahliwaris non muslim (Analisis penetapan pengadilan agama Badung nomor: 4Pdt.P/2013/PA.Bdg Tanggal 7 Maret 2013). Jurnal Ilmu Hukum, 16(1), 25-37. https://doi.org/10.30996/dih.v16i1.2654

Ibnu Mājah, I. al-H. A. A. M. bin Y. al-R. (1999). Bāb Lā wasiyyata li wārith. In Sunan Ibn Mājah. Riyadh: Dār al-Salām. 
Istiqamah, I. (2017). Tinjauan yuridis pembagian harta warisan pasangan suami istri yang beda agama (Pesrpektif hukum Islam dan KUH Perdata). Jurisprudentie, 4(1), 5467.

https://doi.org/10.24252/jurisprudentie.v4i1.3664

Khairani. (2012). Wasiat Wajibah dalam Pemikiran Hukum Ibn Hazm. Banda Aceh: Searfiqh.

Direktorat Jenderal Peradilan Agama. (2001). Kompilasi Hukum Islam. Instruksi Presiden Nomor 1 Tahun 1991. Jakarta: Mahkamah Agung RI.

Manan, A. (1998). Beberapa masalah hukum tentang wasiat dan permasalahannya dalam konteks kewenangan peradilan agama. Mimbar Hukum Aktualisasi Hukum Islam, 38(Tahun IX, 1998).

Muhibbin, M., \& Wahid, A. (2009). Hukum Kewarisan Islam: Sebagai Pembaruan Hukum Positif di Indonesia. Jakarta: Sinar Grafika.

Muslim, I. (1988). Shahih Muslim. Kairo: Dar al-Hadits.

Mutmainah, I., \& Sabir, M. (2019). Wasiat wajibah bagi ahli waris beda agama (Analisis terhadap putusan Mahkamah Agung nomor: 368K/AG/1995). Diktum: Jurnal Syariah Dan Hukum, 17(2), 188-210. https://doi.org/10.35905/diktum.v17i2.818

Piaw, C. Y. (2006). Kaedah dan Statistik Penyelidikan: Asas Statistik Penyelidikan buku 2. Kuala Lumpur: McGraw-Hill Companies.

Raharjo, A. P., \& Dwi Putri, E. F. (2019). Analisis pemberian wasiat wajibah terhadap ahli waris beda agama pasca putusan Mahkamah Agung nomor $331 \mathrm{~K} / \mathrm{Ag} / 2018$. Jurnal Suara Hukum, 1(2), 172-185. https://doi.org/10.26740/jsh.v1n2.p172-185

Ridha, R. (n.d.). Tafsir al-Qur'an al-Hakim, Volume II. Qāhirah: Maktabah al-Qahirah.

Setiawan, E. (2017). Penerapan wasiat wajibah menurut Kompilasi Hukum Islam (KHI) dalam kajian normatif yuridis. Muslim Heritage, 1(2), 43-62. https://doi.org/10.21154/muslimheritage.v2i1.1045

Sukarna, K., \& Hambali, J. K. (2017). Implementasi hak atas ahli waris anak kandung non muslim dalam perspektif hukum Islam yang berlaku di Indonesia. Jurnal Ius Constituendum, 2(2), 170-182. http://dx.doi.org/10.26623/jic.v2i2.659

Syarifuddin, A. (2004). Hukum Kewarisan Islam. Jakarta: Kencana.

Usman, S., \& Somawinata, Y. (1997). Fiqh Mawaris: Hukum kewarisan Islam. Jakarta: Gaya Media.

Yudistiawan, R. (2018). Putusan-putusan mahkamah agung yang "bertentangan" dengan nash. Jurnal Aqlam: Journal of Islam and Plurality, 3(2), 248-264. https://doi.org/10.30984/ajip.v3i2.724

\footnotetext{
i Ibn Hazm juga menyatakan bahwa "diwajibkan bagi setiap Muslim untuk berwasiat kepada sanak kerabat yang tidak menerima harta pusaka baik karena perbudakan, perbedaan agama, terhalang maupun dikarenakan bukan ahli waris. Hendaknya dia berwasiat sekehendaknya, tidak ada Batasan berapa. Seandainya ia meninggal dan tidak berwasiat, maka ahli waris harus memberikan kepada mereka yang dianggap layak". Beliau juga menambahkan bahwa jika orangtuanya atau salah dari keduanya beragama lain, atau menjadi budak, wajib pula baginya untuk memberikan wasiat kepada keduanya atau salah satunya meskipun ia tidak berwasiat, maka tetap harus dikeluarkan wasiatnya setelah itu itu baru boleh berwasiat untuk yang lain.
} 